\title{
Marine organisms as source of bioactive molecules applied in restoration projects
}

\author{
Giovanna Barresi ', Enza Di Carlo ${ }^{1}$, Maria Rosa Trapani ${ }^{1}$, Maria Giovanna Parisi ${ }^{2}$, Chiara Chille ${ }^{1}$, Maria Francesca Mule ${ }^{1}$ \\ Matteo Cammarata ${ }^{2}$ and Franco Palla ${ }^{{ }^{*}}$
}

\begin{abstract}
In recent decades research in the conservation and restoration field has provided sustainable alternatives to traditional procedures for cleaning or controlling the microbial colonization of works of art. In the present study, for the first time novel bioactive molecules extracted from marine invertebrate organisms (Anthozoa) were tested instead of chemical compounds for removing protein layers or as a biocide for controlling fungal or bacterial colonization. In particular, Bioactive Molecules with Protease activity (BMP), acting in a temperature range of $4-30^{\circ} \mathrm{C}$, were tested for the hydrolysis of protein layers on laboratory specimens. The cleaning protocol provides a selective procedure to avoid damage to the original materials constituting the heritage object.

Concurrently, enzymatic cleaning was also performed using commercial Protease from Aspergillus sojae (Type XIX), in order to compare their hydrolytic activities. Bioactive Molecules with Antimicrobial activity $\left(\mathrm{BMA}_{1}, \mathrm{BMA}_{2}\right)$ were tested to control bacterial (Bacillus, Micrococcus) or fungal (Aspergillus, Penicillium) growth, previously isolated from colonized canvas samples and characterized by an integrated approach based on in vitro culture, microscopy and molecular investigations. These molecules were tested to define the Minimal Inhibitory Concentration (MIC) and Minimal Bactericidal/ Fungicidal Concentration (MBC/MFC). Specifically, BMAs were used to control fungal growth during the relining of the painting (laboratory specimens), carried out using a canvas support, and glue paste as binder.

In our hypothesis, these molecules provide an important contribution to the development of innovative protocols for biocleaning or microbial growth control, based on fast and easy application, operator friendly and environmentally sustainable molecules.
\end{abstract}

Keywords: Marine invertebrate, Biocleaning, Protein layer, Protease, Antimicrobial peptides, Biodegradation control

\section{Findings}

Great progress has recently been made in the application of bioactive molecules isolated from marine organisms such as sponges, jellyfish, sea-anemones, shellfish (Blue-Biotechnology) representing an important resource useful to the health, food and processing or preservation industries [1-3]. The peculiarities of these molecules are stability, activity at low-temperature and specificity of action. For these reasons new molecules from the body of invertebrate marine organisms (Anthozoa) [4]

\footnotetext{
* Correspondence: franco.palla@unipa.it

'Dipartimento di Scienze e Tecnologie Biologiche Chimiche e Farmaceutiche (STEBICEF), Università degli Studi di Palermo Laboratorio di Biologia e Biotecnologie per i Beni Culturali, Via Archirafi 28, 90123 Palermo, Italy Full list of author information is available at the end of the article
}

were extracted and applied for biocleaning or controlling microbial growth on heritage objects.

The earliest biocleaning attempts date back to 1970, initially performed to remove animal glue layers from paper, canvas and polychrome artefacts, and later to hydrolyze glue paste or protein/oily binder $[5,6]$. Another available alternative to enzymatic cleaning (stones) is the use of sulphate-reducing bacteria (Desulfovibrio spp.), nitrate-reducing bacteria (Pseudomonas stutzeri) and others [7-9]. Combining the metabolic activity of viable Pseudomonas stutzeri with enzymatic action (Protease) protein layers were removed from the surface of frescoes [10].

In this study, Bioactive Molecules (BMs) with Proteolytic (BMPs) or Antimicrobial (BMAs) activity were utilized for the biocleaning of casein layers, or to control the microbial growth on glue paste-canvas substrates. BMs 
were extracted from the body of marine organisms by homogenization (Ultra-Turrax-5 minutes in ice) in TBS (150 mM NaCl/10 mM Tris- $\mathrm{HCl} \mathrm{pH}$ 7.4) buffer, centrifuged $\left(20^{\prime}-21,000 \mathrm{~g}-4^{\circ} \mathrm{C}\right)$ and the supernatant recovered. Proteins were analyzed by SDS-polyacrylamide gels, using $5 \%(\mathrm{w} / \mathrm{v})$ stacking $-15 \%(\mathrm{w} / \mathrm{v})$ separating gel. After running (190 V-45 minutes) the gel was stained in Coomassie solution (2 gr C-Brillant-Blue/500 ml methanol/100 ml acetic acid $/ 400 \mathrm{ml} \mathrm{d}$-water) and de-stained (10\% acetic acid $/ 40 \%$ methanol $/ 50 \%$ d-water). Protein content was estimated by the Bradford method (standard = Bovine Serium Albumine) [11].

The BMPs showed a high gelatinolytic activity that disappears after adding 1.10-Phenanthroline (metalloproteinase-inhibitor), suggesting that it is a metalloproteinase [12]. Casein layers were stratified on specimens surfaces in order to mimic the removal of overflowing, disfiguring or simply an altered repainting, frequently performed during the lifetime of the painting.

Cleaning tests were carried out on a $2 \mathrm{~cm}^{2}$ casein layer on oil painting specimens laid on linen canvas: $i$ ) a preparatory ground ( $\mathrm{CaCO} 3 /$ linseed oil/ochre pigment); ii) a first paint layer (linseed oil/dark green pigment); iii) a second paint layer (casein medium binder/yellow ochre), on which the enzymes act. The first green (for 2,000 hours) and the second casein (for 2,220 hours) layers were artificially aged (UV-A 300-400 nm; $\mathrm{T}=22 \pm 5^{\circ} \mathrm{C}$; $\mathrm{RH}=$ 60-65\%).

The casein layer was removed by BMP solution in $10 \mathrm{mM}$ Tris-HCl pH 7.5 (without any marine salt addition) or by Commercial Protease, as powder dissolved in $10 \mathrm{mM}$ Tris- $\mathrm{HCl} \mathrm{pH} \mathrm{7.5;} \mathrm{both} \mathrm{gelled} \mathrm{in} \mathrm{5 \%}$ Klucel, (Idrossi-propilcellulose) and stratified on the specimen surface by plastic tips of volume variable pipettes. Gelling agents (Pluronic F108 25-30\%, Vanzan NFC 2$3 \%$, Klucel-G 4-5\%), were tested at different concentrations in order to identify an adequate enzyme support (viscosity, water release), guarantying stable reaction conditions and facilitating the cleaning procedure. The Yellow casein layer was selectively removed after $10 \mathrm{~min}$ of application, by both BMP or commercial protease solutions (Figure 1) without any undesired effects, as specifically assessed for BMP by portable spectrophotometer Konica-Minolta-CM-2600d (sensitivity-ranging 360$740 \mathrm{~nm}$, acquisition-pitch $10 \mathrm{~nm}$ ). Colorimetric measurements (Table 1) were performed on the green layer: before (1) and after being covered by the yellow casein layer (2); finally, after removing the yellow casein layer by BMP (3). On the green layer, BMP cleaning revealed no undesired effects as reported in Table 1: $\Delta \mathrm{E}(1-3)$ value, after removal of the yellow casein layer (2) was 0.96 ; a value well below $\triangle \mathrm{E} 1.5$ perceptible to the human eye [13]. Interestingly, the BMP enzyme was used at a significantly lower concentration $(1 \mathrm{mg} / \mathrm{ml})$ 1:10 with respect to the commercial one,

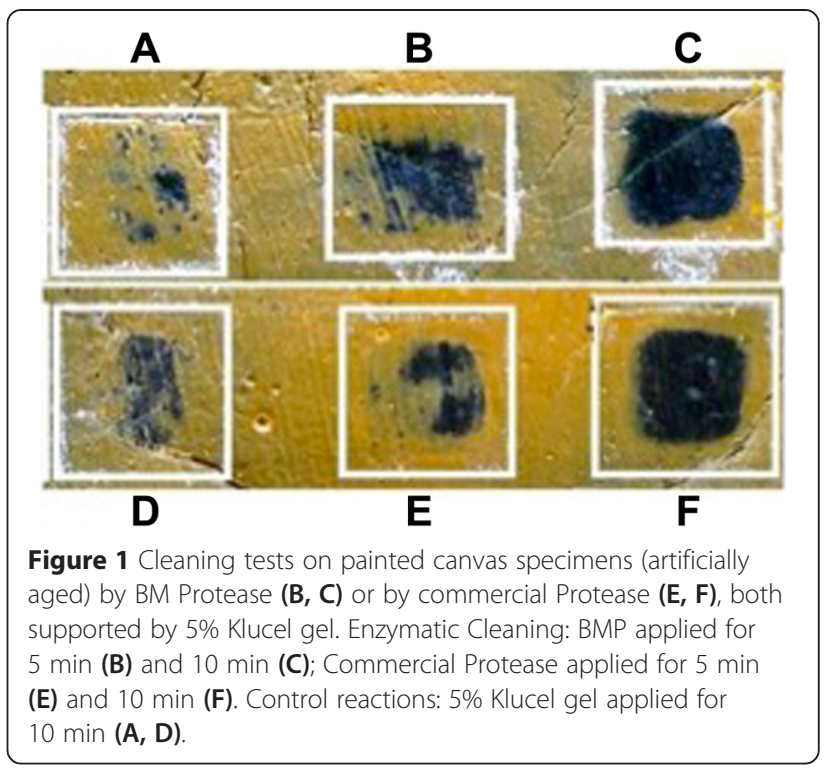

and applied at room temperature $\left(19-26^{\circ} \mathrm{C}\right)$ while for commercial protease, heating at $37^{\circ} \mathrm{C}$ was needed. A negative control test was conducted, applying the gelled solution $(\mathrm{pH}$ 7.5) free from the addition of any enzyme, for each experiment.

In order to control and/or inhibit microbial colonization, other BMAs were tested as potential "biocide molecules". It is well known that a wide range of fungi and bacteria are capable of growing on oil painting adhesive and canvases, and some have been observed after the relining of degraded canvases [14]. In our laboratory, fungi and bacteria that are able to colonize glue paste - canvas specimens were preliminarily isolated and characterized by microscopy and molecular techniques [15-17]. Particularly, Aspergillus sp. and Penicillium sp. conidiophores-conidia structures were observed (Figure 2A) under Scanning Electron (Leica CambridgeLeo 420) after coated with gold particles and Optical Microscopy (Leica DMIL) after Lugol staining (Figure 2B).

Table 1 Colour values, were calculated through the CIE $1976 L^{*}, a^{*}, b^{*}$ (CIELAB) coordinate

\begin{tabular}{|c|c|c|c|c|}
\hline \multicolumn{5}{|c|}{ Spectrophotometric measurements } \\
\hline Preparatory layer & $L^{*}$ & $a^{*}$ & $\mathbf{b}^{*}$ & $\Delta$ \\
\hline 1) Green pigment layer & 25,93 & $-1,88$ & 1,52 & \\
\hline 2) Yellow casein layer & 47,49 & 4,42 & 26,45 & \\
\hline$\Delta(1-2)$ & $\Delta \mathbf{L}^{*}-20,8$ & $\Delta \mathbf{a}^{*} 6,79$ & $\Delta \mathbf{b}^{*}-24,6$ & $\Delta \mathrm{E} 32,92$ \\
\hline \multicolumn{5}{|l|}{$\begin{array}{l}\text { After removal of } \\
\text { yellow casein layer }\end{array}$} \\
\hline 3) Green layer & 26,69 & $-2,4$ & 1,85 & \\
\hline$\Delta(1-3)$ & $\Delta L^{*} 0,76$ & $\Delta \mathbf{a}^{*}-0,49$ & $\Delta \mathbf{b}^{*} 0,33$ & $\Delta \mathrm{E} 0,96$ \\
\hline
\end{tabular}

$\mathrm{L}^{*}, \mathrm{a}^{*}, \mathrm{~b}^{*}$ are the conventional "Color space" defined by the CIE (CIELAB) [13]. 

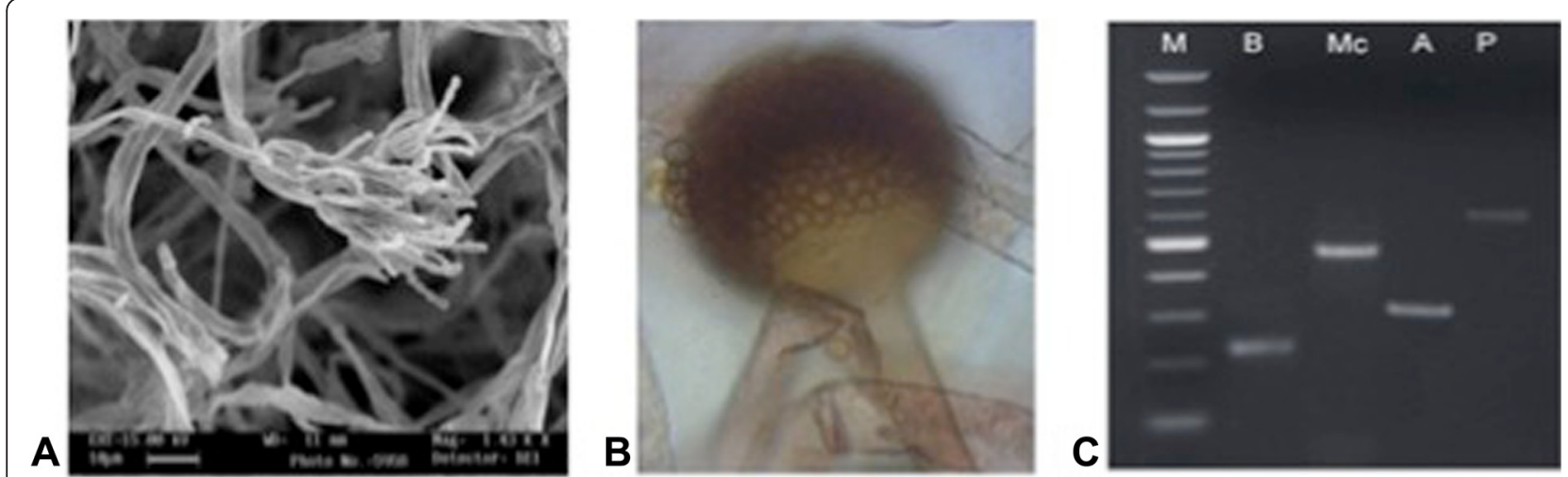

Figure 2 Bacteria and fungi identification by integrated approach. Microscopy analysis: A) SEM micrograph Penicillium; B) Optical observation of Lugol stained Aspergillus conidiophore and conidia; Molecular investigation: C) PCR reaction products resolved on 2\% Agarose gel, corresponding to bacteria Bacillus (lane B) and Micrococcus (lane Mc) and to fungi Aspergillus (lane A) and Penicillium (lane P). M= molecular weight marker, 100 bp DNA ladder

Fungi were identified by in vitro amplification of rRNAInternal Transcribed Sequences (Figure 2C, lanes $\mathrm{A}$ and $\mathrm{P}$ ) as well as for bacterial colonies (Figure 2C, lanes $\mathrm{B}, \mathrm{M}$ ).

Antimicrobial activity of $\mathrm{BMA}_{1}$ and $\mathrm{BMA}_{2}$ was tested against these microbial taxa, establishing the MIC (Minimal Inhibitory Concentration) and the $\mathrm{MBC} / \mathrm{MFC}$, Minimal Bactericidal/Fungicidal Concentration [18-20]. Laboratory tests were performed on two different sets of twelve glue paste - canvas specimens. BMAs or Nipagin-M solutions (final concentration of $1.4 \mathrm{mg} / \mathrm{ml}$ ) were added in $2.5 \mathrm{ml}$ of glue paste, followed by its deposition on linen or synthetic canvas.

As shown in Figure 3B, C, D, the addition of $\mathrm{BMA}_{1}$, or $\mathrm{BMA}_{2}$ or Nipagin-M (Methylparaben) to glue paste- linen specimens, inhibited fungal growth; in absence an extended colonization occurred (Figure 3A). Tests on glue paste- synthetic canvas showed an evident Aspergillus niger growth when any BMAs were added (Figure $3 \mathrm{E}$ ), while a total growth inhibition was in presence of $\mathrm{BM}_{1}$ (Figure $3 \mathrm{~F}$ ) and a partial antifungal activity was in the presence of $\mathrm{BM}_{2}$ (Figure 3G) or Nipagin-M (Figure 3H).

We demonstrate that these bioactive molecules can be utilized in cultural heritage field, by implementing the efficiency of applicative protocols, according to the conservative restoration procedure. This study focalizes on sustainable restoration alternatives which are both operator and environment-friendly, reducing costs and operating times.
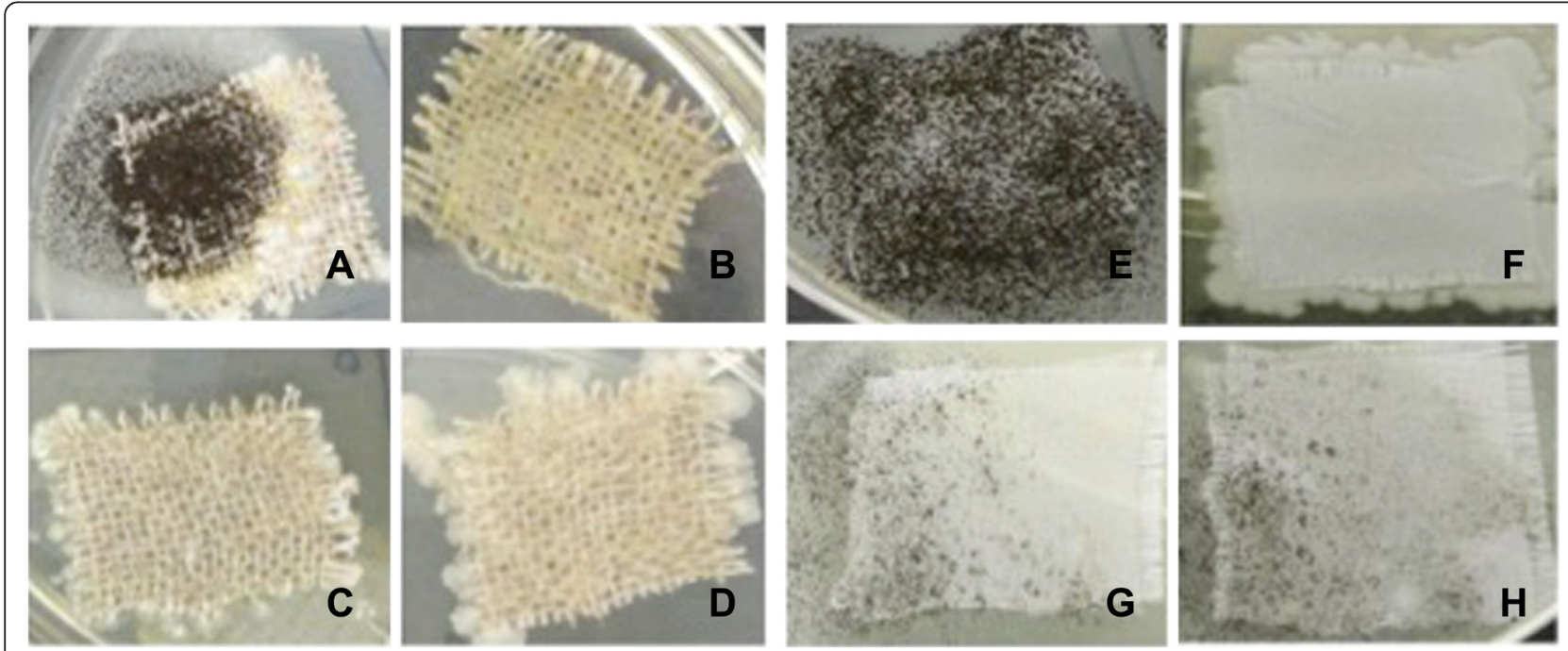

Figure 3 Microbial growth inhibition in glue paste-canvas specimens by BMAs. Fungal growth (Aspergillus niger): absence of antimicrobial molecules in glue-paste linen canvas (A) or glue paste - synthetic canvas (E) specimens. Fungal growth is completely inhibited on linen canvas by BMA $\mathbf{( B}$ ), or $\mathrm{BMA}_{2}(\mathbf{C})$ or Nipagin-M (D) and on synthetic canvas by $\mathrm{BM}_{1}(\mathbf{F})$. A reduced fungal growth is showed in glue paste - synthetic canvas specimens in presence of $\mathrm{BMA}_{2}(\mathbf{G})$ or Nipagin-M $(\mathbf{H})$ molecules. 


\section{Competing interests}

The research was carried out in the absence of any commercial or financial relationships that could be a potential conflict of interest.

\section{Authors' contributions}

$\mathrm{GB}, \mathrm{EDC}$, isolated and characterized microbial colonies, interpreted the results and participated in drafting the paper; MFM and CC, set up the specimens, performed the enzymes solutions and the enzyme action test; MRT, GP isolated the bioactive molecules from invertebrate marine organisms and analyzed their biological activity; MC and FP acquired and interpreted analyses and wrote the manuscript. All authors have read and approved the final manuscript.

\section{Acknowledgements}

This study was developed within the research project It@cha, "Ricerca e Competitività 2007-2013", PON 01_00625 (FP) and partially supported by FFR-UNIPA research grant (MC). A special acknowledgement to Laboratorio U.O. VIII di Fisica - Centro Regionale per la Conservazione e il Restauro Palermo for spectrophotometer measurement and S. Schiavone for processing the colorimetric values. Thanks also to Carmela Di Liberto for SEM analysis.

\section{Author details}

'Dipartimento di Scienze e Tecnologie Biologiche Chimiche e Farmaceutiche (STEBICEF), Università degli Studi di Palermo Laboratorio di Biologia e Biotecnologie per i Beni Culturali, Via Archirafi 28, 90123 Palermo, Italy.

${ }^{2}$ Laboratorio di Immunobiologia Marina, Via Archirafi 18, 90123 Palermo, Italy.

Received: 30 May 2014 Accepted: 28 April 2015

Published online: 25 May 2015

\section{References}

1. Salomone M, Cuttitta A, Seidita G, Mazzola S, Bertuzzi F, Ricordi C, et al. Characterization of collagenolytic/proteolytic marine enzymes. Chem Eng Trans. 2012;27:1-6.

2. Otero-Gonzàlez AJ, Magalhañes BS, Garcia-Villarino M, Lòpez-Abarrategui C, AmaroSousa D, Campos SD, et al. Antimicrobial peptides from marine invertebrates as a new frontier for microbial infection control. FASEB J. 2010;24:1320-34

3. Smith VJ, Desbois AP, Dyrynda EA. Conventional and unconventional antimicrobials from fish, marine invertebrates and micro-algae. Mar Drugs. 2010;8:1213-62.

4. Li H, Parisi MG, Parrinello N, Cammarata M, Roch P. Molluscan antimicrobial peptides, a review from activity-based evidences to computer-assisted sequences. Invertebr Surviv J. 2011;8:85-97.

5. Wendelbo O, Fosse B. A restoring procedure applied on paper. Restaurator. 1970;1:245-8.

6. Cremonesi P. Gli enzimi nella pulitura di opere policrome. Padova: II Prato; 1999.

7. Cappitelli F, Toniolo L, Sansonetti A, Gulotta D, Ranalli G, Zanardini E, et al. Advantages of using microbial technology over traditional chemical technology in removing of black crusts from stone surfaces of historical monuments. Appl Environ Microbiol. 2007:72:5671-5.

8. Bosch-Roig P, Ranalli G. Biocleaning of animal glue on wall paintings by Pseudomonas stutzeri. Chemistry Today. 2013;31(1):50-3.

9. Bosch-Roig P, Regidor-Ros JL, Montes-Estellés RM. Biocleaning of nitrate alterations on wall paintings by Pseudomonas stutzeri. Int Biodeter Biodegr. 2013;84:266-74.

10. Ranalli G, Belli C, Alfano G, Lustrato G, Colombini MP, Bonaduce I, et al. Biotechnology applied to cultural heritage: biorestoration of frescos using viable bacterial cells and enzymes. J Appl Microbiol. 2005:98:73-83.

11. Bradford MM. A rapid and sensitive method for the quantitation of microgram quantities of protein utilizing the principle of protein-dye binding. Anal Biochem. 1976;72:248-54.

12. Mackay AR, Ballin M, Pelina MD, Farina AR, Nason AM, Hartzler JL, et al Effect of phorbol ester and cytokines on matrix metalloproteinase and tissue inhibitor of metalloproteinase expression in tumor and normal cell lines. Invasion Metastasis. 1992:12:168-84.

13. CIE 15: 2004. Colorimetry, 3rd edition, 2004

14. Hackney S: Paintings on Canvas, Lining and Alternatives. TATE Papers, 2013: 1-12.
15. Palla F. Analytical techniques. In Science and Conservation for Museum Collections. Edited by Fabbri B, Nardini: Firenze; 2012: 459-470

16. Palla F, Billeci N, Mancuso FP, Pellegrino L, Lorusso LC. Microscopy and molecular biology techniques for study biocenosis diversity in semi-confined environments. Conservation Science in Cultural Heritage. 2010;10:185-94.

17. Palla F, Barresi G, Di Carlo E. Identification of bacterial taxa in archaeological waterlogged wood. Conservation Science in Cultural Heritage. 2014;14:247-62.

18. Klare I, Konstabel C, Muller-Berting S, Reissbrodt R, Huys G, Vancanneyt M, et al. Evaluation of new broth media for microdilution antibiotic susceptibility testing of lactobacilli, pediococci, lactococci and bifidobacteria. Appl Environ Microbiol. 2005;7:8982-898.

19. Domig KJ, Mayrhoter S, Zitz U, Mair C, Petersson A, Amtmann E. Antibiotic susceptibility testing of Bifidobacterium thermophilum and Bifidobacterium pseudolonum: Broth microdiluition vs. agar disc diffusion assay. Int J Food Microbiol. 2007;120:191-5.

20. National Committee for Clinical Laboratory Standards. Reference method for both dilution antifungal susceptibility testing of yeasts; Approved standard Second edition. NCCLS document M27-A2. Wayne; PA 22, 15; 2002.

\section{Publish with ChemistryCentral and every scientist can read your work free of charge \\ "Open access provides opportunities to our colleagues in other parts of the globe, by allowing anyone to view the content free of charge." \\ W. Jeffery Hurst, The Hershey Company.}

- available free of charge to the entire scientific community

- peer reviewed and published immediately upon acceptance

- cited in PubMed and archived on PubMed Central

- yours - you keep the copyright

Submit your manuscript here:

http://www.chemistrycentral.com/manuscript/

Chemistry Central 